\title{
Eating Disorders Risks and Over Intake of Energy and Macronutrients among Girl Students in Mitra Keluarga School of Health Sciences
}

\author{
Risiko Gangguan Makan, Asupan Energi dan Zat Gizi Makro yang Berlebih pada Remaja Putri \\ di STIKES Mitra Keluarga
}

Alfi Fairuz Asna ${ }^{1 *}$, Muh Nur Hasan Syah ${ }^{2}$

${ }^{1}$ Fakultas Kesehatan Masyarakat, Universitas Diponegoro; ${ }^{2}$ Program Studi S1 Ilmu Gizi Fakultas Ilmu Kesehatan, UPN Veteran Jakarta

\begin{abstract}
Group of adolescents who have eating behaviour disorders, food intake restrictions, alcohol consumption, drug addiction require special nutritional attention. In 2013 there were $73 \%$ of obese teens in Indonesia. This prevalence increases every year. This study aims to determine the risk of eating disorders and their relationship with excessive food intake. This study was cross sectional design with the simple sixe of 97 girls in grade of university level. Risk of eating disorders was determined by using questionnaires Eating Attitudes Test (EAT-26). Intake of nutrient was collected by semi quantitative questionnaires. Data analyszed by Chi-square test using SPSS. The results found that among girls, 5\% were at high risk of eating disorder, more than 50\% have over intake of energy, protein and fat, and $46,4 \%$ have over intake of carbohydrate. There was no relationship between risk of eating disorder and energy and macronutrient intake. However, those who were at high risk of eating disorder have over intake of energy, carbohydrate, protein, and fat. Adolescent girls who were at high risk of eating disorders have higher intake of energy and micronutrients. It is recommended for further research on eating disorders risks, eating behaviour and body image.
\end{abstract}

Keywords - Eating Disorders, Macronutrient Intake, Obesity

\begin{abstract}
ABSTRAK
Remaja putri yang mempunyai gangguan makan, pembatasan makanan, konsumsi alkohol dan ketergantungan terhadap obat-obatan, membutuhkan perhatian pada asupan zat gizinya. Pada tahun 2013 terdapat 7,3\% remaja yang berstatus gizi obesitas di Indonesia. Prevalensi ini meningkat setiap tahun. Penelitian ini bertujuan untuk mengetahui hubungan antara risiko gangguan makan dan asupan makanan berlebih. Penelitian ini menggunakan desain cross-sectional dengan jumlah sampel 97 remaja putri. Risiko gangguan makan diukur menggunakan kuesioner Eating Attitudes Test (EAT-26). Asupan zat gizi diukur menggunakan semi quantitative food frequency kuesioner. Data yang sudah terkumpul dianalisis menggunakan SPSS. Hasil penelitian menemukan bahwa di antara remaja perempuan, 5\% berisiko tinggi mengalami gangguan makan, lebih dari 50\% memiliki asupan energi, protein, dan lemak berlebihan, dan 46,4\% memiliki asupan karbohidrat berlebih. Tidak ada hubungan antara risiko gangguan makan dan energi dan asupan zat gizi makro. Namun, mereka yang berisiko tinggi mengalami gangguan makan memiliki kelebihan asupan energi, karbohidrat, protein dan lemak.Gadis remaja yang berisiko tinggi mengalami gangguan makan memiliki asupan energi dan gizi mikro yang lebih tinggi. Disarankan untuk penelitian lebih lanjut tentang risiko gangguan makan, perilaku makan dan citra tubuh
\end{abstract}

Keywords - Gangguan Makan, Asupan Makronutrien, Obesitas

\section{INTRODUCTION}

Overweight / obesity is the root of various non-communicable diseases including diabetes, hypertension and cardiovascular disease. Non- communicable diseases are still a major health problem in Indonesia (Purnamasari, 2018). Overweight and obesity are major health problems in both developed and developing countries. 
According to data obtained by Odgen et al the prevalence of obesity increased between 1999 2000 and 2007 - 2008 (Cynthia L Ogden, Susan Z Yanovski, Margaret D Carroll, Katherine M Flegal, 2007). National Health and Nutrition Examinantion Survey (NHANES) $16.9 \%$ of children and adolescents aged 2-19 years are obese . Adolescents who are obese tend to become obese as adults and are more at risk of causing health problems (Sameera Karnik and Amar Kanekar, 2012).

Data from Riskesdas (Indonesian Basic Health Research) (2018) shows that the national prevalence of overweight in adolescents aged 1618 years is $9,5 \%$ and obese $4 \%$ (3). The prevalence of overweight and obese in adolescents aged 16-18 years in West Java is 10,9\% and 4,5\%. Bekasi city is one of the areas that has a higher prevalence of overweight than the prevalence of West Java Province (Balitbangkes, 2018).

Adolescents are a transition from childhood to adulthood who are vulnerable to influence from the environment. One consequence is the occurrence of eating disorders because they want an ideal body shape, especially in young women (Dana K Voelker Justine J Reel,and Christy Greenleaf, 2015). So that it affects a person's actions to perform improper eating behavior so that it can negatively impact nutritional status

Eating disorder is a psychological and medical disorder that causes serious abnormalities in eating behavior to control body weight. Research in Semarang found $67.8 \%$ had eating disorders (Syarafina, 2014). Another study also found $54.6 \%$ of students experienced deviant eating behavior (Santi, 2012). Diet behavior is one of the triggering factors that will become eating diorders behavior (Kessler, RC., et al, 2013) . Prevelence of eating disorders in youth were about $14-22 \%$ (50\% of the experience Binge Eating) (Eleonora Marzilli, Luca Cerniglia,2 and Silvia Cimino, 2018). Binge eating in late adolescene can cause obesity in adult.

This study aims to determine the risk of eating disorders and their relationship with excessive intake.

\section{METHODS}

This research is a cross sectional study. The sample studied was 97 adolescent girls. This research was conducted in March to May 2018, at the Mitra Keluarga School of Health Sciences, Bekasi, West Java. The data collected are Eating Disorder Risk data using the EAT 26 questionnaire, data on energy intake and macro nutrients using a semi quantitative food frequency questionnaire, then analyzed using the chi square test.

\section{RESULTS AND DISCUSSIONS}

Of the 100 randomly selected participants, 3 participants were absent during the days when the test was performed. 97 participants completed questionnaires.

Table 1 Relationship between Eating Disorders Risk with Energy Intake

\begin{tabular}{|c|c|c|c|c|c|c|c|c|c|c|}
\hline Eating & \multicolumn{8}{|c|}{ Intake of Energy } & $x^{2}$ & $\mathbf{p}$ \\
\hline & \multicolumn{2}{|c|}{ Enough } & \multicolumn{2}{|c|}{ Less } & \multicolumn{2}{|c|}{ More } & \multicolumn{2}{|c|}{ Total } & & \\
\hline & $\mathbf{n}$ & $\%$ & $\mathbf{n}$ & $\%$ & $\mathbf{n}$ & $\%$ & $\mathbf{n}$ & $\%$ & & \\
\hline High & 1 & 20 & 1 & 20 & 3 & 60 & 5 & 10 & 1,2 & 0,5 \\
\hline Risk & & & & & & & & 0 & 2 & 4 \\
\hline Low & 8 & 8,7 & 37 & 40 , & 47 & 51, & 92 & 10 & & \\
\hline Risk & & & & 2 & & 09 & & 0 & & \\
\hline Total & 9 & 9,2 & 38 & 39, & 50 & 51, & 97 & 10 & & \\
\hline & & 8 & & 18 & & 55 & & 0 & & \\
\hline
\end{tabular}

In Table 1 explained that Statistical analysis shows that there is no significant 
relationship between the risk of eating disorders with energy intake. There are $60 \%$ of adolescents who have a high risk of eating disorder, have excessive energy intake.

Table 2. Relationship between Eating Disorders Risk with Carbohydrate Intake

\begin{tabular}{|c|c|c|c|c|c|c|c|c|c|c|}
\hline \multirow{3}{*}{$\begin{array}{c}\text { Eating } \\
\text { Disorder } \\
\text { Risk } \\
\end{array}$} & \multicolumn{8}{|c|}{ Intake of Carbohydrate } & \multirow[t]{2}{*}{$x^{2}$} & \multirow[t]{2}{*}{$\mathbf{p}$} \\
\hline & \multicolumn{2}{|c|}{ Enough } & \multicolumn{2}{|c|}{ Less } & \multicolumn{2}{|c|}{ More } & \multicolumn{2}{|c|}{ Total } & & \\
\hline & $\mathbf{n}$ & $\%$ & $\mathbf{n}$ & $\%$ & $\mathbf{n}$ & $\%$ & $\mathbf{n}$ & $\%$ & & \\
\hline $\begin{array}{l}\text { High } \\
\text { Risk }\end{array}$ & 0 & 0 & 2 & 40 & 3 & 60 & 5 & 10 & 0,7 & 0,6 \\
\hline $\begin{array}{l}\text { Low } \\
\text { Risk }\end{array}$ & 11 & $\begin{array}{l}11, \\
69\end{array}$ & 37 & $\begin{array}{l}40, \\
22\end{array}$ & 44 & $\begin{array}{l}47, \\
83\end{array}$ & 92 & $\begin{array}{c}10 \\
0\end{array}$ & & \\
\hline Total & 11 & $\begin{array}{l}11, \\
34\end{array}$ & 39 & $\begin{array}{c}40 \\
21\end{array}$ & 47 & $\begin{array}{c}48, \\
45\end{array}$ & 97 & $\begin{array}{c}10 \\
0\end{array}$ & & \\
\hline
\end{tabular}

Table 2 explained that Statistical analysis shows that there is no significant relationship between the risk of eating disorders with carbohydrate intake. There are $60 \%$ of adolescents who have a high risk of eating disorder, have excessive carbohydrate intake

Table 3. Relationship between Eating Disorders Risk with Protein Intake

\begin{tabular}{|c|c|c|c|c|c|c|c|c|c|c|}
\hline \multirow{3}{*}{$\begin{array}{c}\text { Eating } \\
\text { Disorder } \\
\text { Risk } \\
\end{array}$} & \multicolumn{8}{|c|}{ Intake of Protein } & \multirow[t]{2}{*}{$x^{2}$} & \multirow[t]{3}{*}{$\mathbf{P}$} \\
\hline & \multicolumn{2}{|c|}{ Enough } & \multicolumn{2}{|c|}{ Less } & \multicolumn{2}{|c|}{ More } & \multicolumn{2}{|c|}{ Total } & & \\
\hline & $\mathbf{n}$ & $\%$ & $\mathbf{n}$ & $\%$ & $\mathbf{n}$ & $\%$ & $\mathbf{n}$ & $\%$ & \multirow{3}{*}{1} & \\
\hline $\begin{array}{l}\text { High } \\
\text { Risk }\end{array}$ & 0 & 0 & 1 & 20 & 4 & 80 & 5 & $\begin{array}{c}10 \\
0\end{array}$ & & $\begin{array}{c}0,6 \\
06\end{array}$ \\
\hline $\begin{array}{l}\text { Low } \\
\text { Risk }\end{array}$ & 12 & $\begin{array}{l}13 \\
04\end{array}$ & 24 & $\begin{array}{c}26 \\
09\end{array}$ & 56 & $\begin{array}{l}60, \\
87\end{array}$ & 92 & $\begin{array}{c}10 \\
0\end{array}$ & & \\
\hline Total & 12 & $\begin{array}{l}12, \\
37\end{array}$ & 25 & $\begin{array}{l}25 \\
77\end{array}$ & 60 & $\begin{array}{l}61, \\
86 \\
\end{array}$ & 97 & $\begin{array}{c}10 \\
0 \\
\end{array}$ & & \\
\hline
\end{tabular}

Table 3 explained that Statistical analysis shows that there is no significant relationship between the risk of eating disorders with protein intake. There are $80 \%$ of adolescents who have a high risk of eating disorder, have excessive protein intake.

Table 4. Relationship between Eating Disorders Risk with Fat Intake

\begin{tabular}{|c|c|c|c|c|c|c|c|c|c|c|}
\hline $\begin{array}{c}\text { Eating } \\
\text { Disorder }\end{array}$ & \multicolumn{8}{|c|}{ Intake of Fat } & \multirow[t]{2}{*}{$\mathbf{x} 2$} & \multirow[t]{2}{*}{$\mathbf{p}$} \\
\hline & \multicolumn{2}{|c|}{ Enough } & \multicolumn{2}{|c|}{ Less } & \multicolumn{2}{|c|}{ More } & \multicolumn{2}{|c|}{ Total } & & \\
\hline & $\mathbf{n}$ & $\%$ & $\mathbf{n}$ & $\%$ & $\mathbf{n}$ & $\%$ & $\mathbf{n}$ & $\%$ & \multirow{3}{*}{0,9} & \\
\hline $\begin{array}{l}\text { High } \\
\text { Risk }\end{array}$ & 0 & 0 & 1 & 20 & 4 & 80 & 5 & $\begin{array}{c}10 \\
0\end{array}$ & & $\begin{array}{c}0,6 \\
4\end{array}$ \\
\hline $\begin{array}{l}\text { Low } \\
\text { Risk }\end{array}$ & 1 & $\begin{array}{c}1,0 \\
9\end{array}$ & 37 & $\begin{array}{l}40, \\
22\end{array}$ & 54 & $\begin{array}{c}58, \\
7\end{array}$ & 92 & $\begin{array}{c}10 \\
0\end{array}$ & & \\
\hline Total & 1 & $\begin{array}{c}1,0 \\
3\end{array}$ & 38 & $\begin{array}{c}39, \\
18 \\
\end{array}$ & 58 & $\begin{array}{l}59, \\
79\end{array}$ & 97 & $\begin{array}{c}10 \\
0 \\
\end{array}$ & & \\
\hline
\end{tabular}

Table 4 explained that Statistical analysis shows that there is no significant relationship between the risk of eating disorders with fat intake. There are $80 \%$ of adolescents who have a high risk of eating disorder, have excessive fat intake

This result is similar with research conducted by Kurniawan et al, where female students with eating disorders only $7.8 \%$. (Kurniawan, MY, Dodik Briawan, 2014). Similar results also occurred in the Yogyakarta study, only $12.2 \%$ of adolescent girls had an eating disorder risk. The results by Chang, et al (2011) mention that $17,11 \%$ of participants had high risk of eating disorders. The risk of eating disorders is most likely in adolescents with negative body perceptions (Chang. YJ, Lin.W, \&Wong. Y, 2011).

The primary defining characteristic of a diagnosis of an eating disorder (ED) is the "disturbance of eating or eating-related behavior that results in the altered consumption or absorption of food. Recent work on obesity and substance use disorders has identified behaviors and neural pathways that play a powerful role in human consummatory behav-iors. these systems also occur in ED (Wierenga, 2014).

Over intake energy and macronutrient related to reward, and that this altered reward 
related to emotional dysregulation, manifesting as exaggerated anxiety and sensitivity to punishment (Bert Schreurs, Hannes Guenter, Ute Hülsheger, Hetty van Emmerik, 2014). Individuals with AN (anorexia nervosa) may compensate for dysfunctional reward processing using exaggerated cognitive control. Those with $\mathrm{BN}$ (Bulimia nervosa) may have deficient cognitive control increasing instability and erratic responding to appetitive stimuli. (Wierenga, 2014).

\section{CONCLUSION}

Although there is no relationship between ED (Eating Disorders) and food intake, there are samples with a risk of eating disorders that have excessive macronutrient intakes.

\section{ACKNOWLEDGEMENT}

This research is funded by Mitra Keluarga School of Health Science

\section{REFERENCES}

Balitbangkes. (2018). Riset Kesehatan Dasar. Jakarta.

Bert Schreurs, Hannes Guenter, Ute Hülsheger, Hetty van Emmerik. (2014). The Role of Punishment and Reward Sensitivity in the Emotional Labor Process: A Within-Person Perspective. J Occup Health Psycho, 10821.

Chang. YJ, Lin.W, \&Wong. Y. (2011). Survey on eating disorder-related thoughts, behaviors, and their relationship with food intake and nutritional status in female high school students in Taiwan. Journal of the Am Coll Of Nut , 39-48.

Cynthia L Ogden, Susan Z Yanovski, Margaret D Carroll, Katherine M Flegal. (2007). The Epidemiology of Obesity. Gastroenterology , 2087-102.
Dana K Voelker Justine J Reel,and Christy Greenleaf. (2015). Weight status and body image perceptions in adolescents: current perspectives. Adolesc Health Med Ther, 149-158.

Eleonora Marzilli, Luca Cerniglia,2 and Silvia Cimino. (2018). A narrative review of binge eating disorder in adolescence: prevalence, impact, and psychological treatment strategies. Adolesc Health Med Ther , 1730 .

Kessler, RC., et al. (2013). The prevalence and corelates of binge eating disorder in the WHO World Mental Health Surveys. . Biol Psychiatry., 904-914.

Kurniawan, MY, Dodik Briawan. (2014). Persepsi tubuh dan gangguan makan pada remaja. Jurnal Gizi dan Pangan .

Purnamasari, D. (2018). The Emergence of Noncommunicable Disease in Indonesia. Acta Med Indones - Indones J Intern Med, 273274.

Sameera Karnik and Amar Kanekar. (2012). Childhood Obesity: A Global Public Health Crisis. Int J Prev Med. , 1-7.

Santi, M. (2012). Faktor-faktor Yang Mempengaruhi Kecenderungan Perilaku Makan menyimpang Pad aMahasiswa Di Fakultas Kedokteran dan Ilmu Kesehatan Universitas Islam Negeri Syarif Hidayatullah. Jakarta.

Syarafina, A. (2014). Hubungan Eating Disorder dengan Status Gizi Pada Remaja Putri di Modeling Agency Semarang. Journal of Nutrition College , 48-53.

Wierenga, C. A.-G. (2014). Are extremes of consumption in eating disorders related to an altered balance between reward and inhibition? . Behavioral Neuroscience, 111. 